\title{
Fish Species Diversity And Abundance Of Tagwai Dam Minna, Niger State
}

\author{
${ }^{1}$ Orire A.M, S.O.E Sadiku and ${ }^{2}$ Emmanuel, A.J \\ ${ }^{I}$ Department of Water Resources, Aquaculture And Fisheries Technology, \\ Federal University of Technology, P.M.B 65, Minna, Niger State-Nigeria
}

\begin{abstract}
Fish species diversity of Tagwai Dam (Longitude $6^{\circ} 39$ to $6^{\circ} 44$ East and Latitude $34^{\circ}$ to $9^{\circ} 37$ North to South-west of Minna were studied. The sampling was conducted fortnightly for three. Five species from five genera and five families were identified. These were Clupeidae, Cichlidae, Bagridae, Clarridae, Mochokidae and Cyprinidae. The total count for species during the sampling period was 13,773. Clupeidae were the most dominant species with a total counts of $(7,897)$ while Labeo (Cyprinidae) had the least population. There were significant differences $(P<0.05)$ in the weight of the samples of species obtained. There was also significant difference $(P<0.05)$ between the Tilapia species and Clupeid species. However, but there was no significant difference $(P>0.05)$ among the species of Clarias, Synodontis and Labeo whose population were the lowest. Adoption of fish conservation and management strategies and enforcements of fisheries by-laws are necessary to improve the fishery resource of the Tagwai dam coupled with regular bio-diversity study of the Dam.
\end{abstract}

Key words: Fish species, diversity and abundance.

\section{Introduction}

Conservation strategies are human modifications to the environment as measure against overexploitation, habitat loss, exotic species and others (Nguyen, 2006). Aquatic biodiversity is greatly threatened which affects sustainable environment and in order to preserve these threatened areas and species for further generations, immediate action in the form of aquatic biodiversity conservation strategies are necessary. In general, aquatic conservation strategies should sustain development by protecting biological resources in ways that will preserve habitats and ecosystems. In order for biodiversity conservation to be effective, management measures must be broad based.

Aquatic diversity management as proposed by Moyle and Yoshiyama (1994) are a systematic management approach for lakes and water sheds, where the primary goal is to protect the aquatic biodiversity in a given area. The best way to properly manage Adams is to stop or greatly reduce all human activities contributing to habitat degradation in that area. This concept has been applied in the Sierra Nevada area. Some studies have been carried out on this dam (Maishanu, 2002, Ojutiku, 2008) both reports indicated fluctuations in species abundance and diversity (Ojutiku, et al. 2009). The relevance of biodiversity of aquatic resource can be observed in the convention on International Trade in Endangered Species (CITES) which during its world conference 1992, world conference on environment held in Rio de janeiro in 1992, members were convinced to sign two conventions; one dealing with Biodiversity and the other on the climate change (Russel et al., 1994). On this regard, several research works have been done both on terrestrial and aquatic resources (Russel et al., 1994)). On Nigeria Rivers, Ita, 1990 reported, an estimated total of about 230 fish species. Olaosebikan and Raji (1998) listed more than 268 fish species from 35 families in Nigeria freshwater bodies. Biodiversity is the basic determinants of structure and function of ecosystems on which wellbeing of human rested upon, this, however, calls for proper understanding of resource management and its preservation (Vakily et al., 1997). The biodiversity of Africa fishery resource have been reported to be dominated by otophysans (cyprinidis, characiforms, and a few catfsh families) along with momyrids and cypridontiformes while lacustrine are completely dominated by cichlid species (Lundberg et al., 2000). According to Stiassny (1996), 58\% of fishes are marine, $41 \%$ freshwater while only $1 \%$ migrates between salt and freshwater. From this data, only $25 \%$ of freshwater fishes is concentrated into less than $0.01 \%$ of the earth's water. This brings to mind the need to conserve the biodiversity since its destruction implies their loss or reduction (Ogden et al., 1994). It has been reported that, human activities have rendered many species into extinction (Magin et al., 1994) as was the case with Lake Victoria which some 30 years ago habituated over 300 species of cichlidis but has been decimated greatly (Witte et al., 1992). Mishanu (Ojutiku et al., 2009) studied biodiversity of Tagwai dam 2002 and reported that it containing 9 families, 5 genera (Ojutiku et al., 2009). Therefore, the present study seeks to determine the prevailing condition of the fish community in the Tagwai dam, Niger State-Nigeria. 


\section{Materials And Methods}

Tagwai Dam has a total surface area of 44 hactres and storage capacity of 28.3 million $\mathrm{m}^{3}$ of water (Alkali, 1994). It has a depth of 25 metres and a length of $18 \mathrm{Km}\left(45,000 \mathrm{~m}^{3}\right)$. The dam was constructed in 1980 on (Longitude $6^{\circ} 39$ to $6^{\circ} 44$ East and Latitude $34^{\circ}$ to $9^{\circ} 37$ North to South west of Minna). The dam has two spill way of 100 and $170 \mathrm{~m}$ long respectively. It is located in Chanchaga Local Government area of Niger state, Nigeria (Alkali, 1994). Data was collected from fishermen twice in a month for a period of three months from February to April, 2009. Sampling was carried out during fish landing locations by the dam site between the jours of 7 and 9am fish landed by all the fishermen on the dam were collected and used for data collection and analyses.

\section{Experimental tools}

The fishermen used fishing tools which included gill net, traps, and canoe. Fishes caught were preserved in ice box for conveying the fishes to the laboratory for analysis. Fishes were further preserved in $10 \%$ formalin solution prepared by mixing 1 litre of $40 \%$ formaldehyde with 3 litres of clean water. The solution was kept in transparent labeled bottles.

\section{Data Collection}

For data gathering, the following were collected; total weight of fish landed by fishermen during each sampling period, total count of fish per species identified, identification and listing of all fish species landed, size range of each species identified and total weight of fish landed. Fishes were weighed with the aid of weighing scale.

\section{Identification of fish samples}

Fishes were identified using keys, monographs, and field guides according to Reed et al (1967), Anthony (1982). Identification was done from species to class levels for fishes caught.

\section{Present situation of Tagwai dam}

As at the time of the study the water level in reservoir was very low as there was evident of high siltation in the reservoir. Farming activities were also seen going on upstream and at the same time the reservoir supplies Minna town with domestic water.

\section{Evaluation}

Data generated were evaluated based on the following formulae;

Species diversity index $=\underline{\text { Number of species in water body }} \times \underline{100}$

$$
\text { Total number of fishes in the water body } 1
$$

Family diversity $=\underline{\text { Number of families in the water body }}$ Total number of fishes in the water body

Species Abundance $=\underline{\text { Number of fish per species }} \times \underline{100}$ Total number of Fish $\quad 1$

\section{Statistical analysis}

Data were analysed using mintab release 14 for determination of level of significance for one way analyses of variance. Means were separated using Turkeys test (Steel and Torrie, 1980, Duncan, 1955)

\section{Result And Discussion}

The sampling carried out on the rersrvoir gave a total of five (5) species belonging to five (5) genera and 5 families were recorded.

Table 1: Fish Species Of Tagwai Dam

\begin{tabular}{lllll}
\hline FISH & \multicolumn{1}{c}{ ORDER } & \multicolumn{1}{c}{ FAMILES } & \multicolumn{2}{c}{ SPECIES } \\
\hline Tilapia & Perciformes & Cichlidae & $\begin{array}{l}\text { Oreochromis } \\
\text { Hemichromis } \\
\text { Zilli }\end{array}$ & niloticus, \\
Clupeid & Clupeiformes & Clupeidae & Clupentos & \\
& & & Clarias gariepinus & \\
Clarias & Siluriniformes & Claridae & Synodontis guttatus \\
Synodontis & Siluriniformes & Mochokidae & Labeo species \\
Labeo & Cypriniformes & Cyprinidae & & \\
\hline
\end{tabular}


Table 2: SPECIES ABUNDANCE OF TAGWAI DAM

\begin{tabular}{|c|c|c|c|}
\hline SPECIES & ABUNDANCE & $\begin{array}{c}\text { RELATIVE } \\
\text { ABUNDANCE }\end{array}$ & SPECIES TYPE \\
\hline Clupeid & 7896 & 57.33 & 1 \\
\hline Tilapia & & & 3 \\
\hline $\begin{array}{r}\text { i. Oreochromis } \\
\text { niloticus }\end{array}$ & 3,268 & 23.73 & \\
\hline $\begin{array}{r}\text { ii. Hemichromis } \\
\text { niloticus }\end{array}$ & 1,635 & 11.87 & \\
\hline iii. Tilapia zilli & 803 & 5.83 & \\
\hline Synodontis & 91 & 0.66 & 1 \\
\hline Clarias & 49 & 0.36 & 1 \\
\hline Labeo & 31 & 0.23 & 1 \\
\hline
\end{tabular}

The total counts per species during the sampling period are presented in Table 2 the clupeid species had the highest population of seven thousand eight hundred and ninety six $(7,896)$. This was followed by Tilapia species with a population of Five thousand seven hundred and six $(5,706)$, followed by Synodontis with the population of ninety one (91), while Clarias were forty nine (49) and the least populated species was Labeo with the population of thirty one (31).

TABLE 3: FISH SPECIES DIVERSITY OF TAGWAI DAM

\begin{tabular}{lccccccc}
\hline \multicolumn{1}{c}{ Species } & Family & Abundance & $\begin{array}{c}(\%) \\
\text { Relative } \\
\text { Abundance }\end{array}$ & $\begin{array}{c}\text { Species } \\
\text { Types }\end{array}$ & $\begin{array}{c}\text { Species } \\
\text { Diversity } \\
\text { index }\end{array}$ & $\begin{array}{c}\text { Weight of } \\
\text { Species (kg) }\end{array}$ & $\begin{array}{c}\text { Species } \\
\text { Occurrence }\end{array}$ \\
\hline $\begin{array}{l}\text { Oreochromis } \\
\text { niloticus. }\end{array}$ & Cichlidae & 5706 & 41.43 & 3 & 0.05 & $18.89 \pm 3.86^{\mathrm{a}}$ & $146.9 \pm 28.60^{\mathrm{a}}$ \\
$\begin{array}{l}\text { Clupeid } \\
\text { mentos }\end{array}$ & Clupidae & 7896 & 57.33 & 1 & 0.01 & $17.76 \pm 6.25^{\mathrm{b}}$ & $550.1 \pm 497.60^{\mathrm{b}}$ \\
$\begin{array}{l}\text { Clarias } \\
\text { gariepinus }\end{array}$ & Claridae & 49 & 0.36 & 1 & 2.04 & $3.32 \pm 3.11^{\mathrm{c}}$ & $3.0 \pm 2.00^{\mathrm{c}}$ \\
$\begin{array}{l}\text { Synodontis } \\
\text { guttatus }\end{array}$ & Mochokidae & 91 & 0.66 & 1 & 1.09 & $1.40 \pm 1.33^{\mathrm{cd}}$ & $1.7 \pm 1.50^{\mathrm{c}}$ \\
$\begin{array}{l}\text { Labeo } \\
\text { species. }\end{array}$ & Cyprinidae & 31 & 0.23 & 1 & 3.23 & $0.73 \pm 0.57^{\mathrm{d}}$ & $2.5 \pm 2.20^{\mathrm{c}}$ \\
Total & & 13,773 & 100.01 & 7 & 4.42 & & \\
\hline
\end{tabular}

The result analysed indicated significant differences $(\mathrm{p}<0.05)$ in the weight of the samples of fish species obtained (Table 3). The weights of species was significant $(\mathrm{P}<0.05)$ for Oreochromis niloticus while labeo was the list significant $(\mathrm{P}<0.05)$ of the all species. On the species occurrence there were significant differences $(p<0.05)$ between the Tilapia species and Clupeid species but there was no significance differences $(p>0.05)$ among the species of Clarias, synodontis and Labeo (3.0, 1.7 and 2.5 respectively).

In Tables 2 and 3 the Clupeid (clupeidae) was the highest in abundance followed by Tilapia (ciichlidea) which was in agreement with the findings of Ojutiku et al (2009) on the same dam. The abundant nature of this species as attributed to absence of predator fishes such as Lates niloticus and Hapsetus odoe was evident as it was in agreement with the report of Ojutiku et al. (2009). Synodontis, Clarias, and Labeo species while in relative. In terms of species type Tilapia was the highest while the remaining species have the same number while in terms of percentage species diversity, Labeo has the highest number followed by Clarias, Synodontis, Clupeid and Tilapia. It is evident from the findings that high valued species such as catfish have low population (Table 3) compared with low valued ones like Tilapia. This is in agreement with the finding of Nguyen (2006) who reported African catfish as among over exploited freshwater fish. However, there was reduction in the family from 6 to 5 as against the Ojutiku et al. (2009) and Mishanu (2002). Capture fisheries in essence poses high risk to conservation of fish species as a result of obnoxious fishing methods adopted by fishermen (Moses, 1983). For the fact that large percentage of fish production in Nigeria comes from artisanal fisheries sector (Talabi, 1986), it raises concern for effective conservation strategies to ensure sustainability of the vulnerable water bodies. Therefore, projecting the findings on the Tagwai Dam to other water bodies in Nigeria obviously reveals the need for proactive measures on the part of conservationists to put in place effective conservation strategies to address challenges being faced by the non-renewable resource. 


\section{Conclusion}

Tagwai Dam with a total area of about $45,000 \mathrm{~m}^{2}$ was found with only few species of fresh waters fishes. The most abundant species included clupidea and cichlidea. The species conservation was low probably because the water source of Tagwai River has no inlet tributaries and the associated problems of bad fishing methods which results in over fishing of the stock thereby altering the biodiversity of the dam. The dam has the potential of supporting fish species if good management procedures are adopted. The dam is important natural resources to Niger State for domestic water supply, fish production and irrigation for agricultural produce.

\section{References}

[1] Alikali, A. L. (1994). Some water quality parameter and potential fish yield of Tagwai Dam, Minna, Niger State. Masters Thesis. Department of Water Resources, Aquaculture and Fisheries Technology, Federal University of Technology, Minna. Niger State.

[2] Anthony A.D and Moses (1982) Identification of Nigeria freshwater fish poothokaren pub. Trichur, India 18pp

[3] Ita, E.O. (1993). Inland Fisheries Resources of Nigeria. FAO CIFA Occasional paper No. 20 p 6.

[4] Lundberg, J.G, Maurice Kottelat, Gerald R. Smith, Melanie, L.J. and Anthony C. Gill (2000). An overview of recent Ichthyological Discovery in Continental Waters 87 (1) 41.

[5] Maishanu, B. (2002) Postgraduate project work. Department of Water Resources, Aquaculture and Fisheries Technology, Federal University of Technology, Minna.

[6] Magin, C.D. Johnson,T.H. , Groombridge, B. Jenkins, M. and Smith, H (1994). Species extinctions, endangerment and captive breeding. In: lan J. Harrison and Melanie, L.J., Stiassny (1999). Extinction in Near Time p 298

[7] Moyle and Yoshiyama (1994) Aquatic diversity Management Area

[8] Nguyen, T.T. (2006). The biodiversity and lost of habitat by overfishing of reshwater fishes in West Africa.

[9] Ogden, J.T. Done and B. Salvat (1994). Biodiversity Issue Takes to the Water. NAGA 17(1)11-12.

[10] Ojutiku, R.O, Kolo, R.J. and Izediunor, B.C (2009). Fish communities of Tagwai Dam, Niger State. Journal of Agriculture, Forestry and the Social Sciences 7(1) 151-157

[11] Olaosebikan, B.D. and Raji, A (1998). Field Guide to Nigerian Freshwater Fishes. FederalCollege of Freshwater Fisheries, New Bussa, Nigeria.

[12] Reed W. J. Buchard, A.J. Hopson, J. Jennes, J. and Yaro, I. (1967) Fish and Fisheries of Northern Nigeria Kaduna Ministry of Agriculture 226 pp

[13] Russel, S; Pimbert,M; and Barkow, B (1994). La diversity de la vie W.W.F P2,7,9,22,23.

[14] Stiassny, M.L.J. (1996). International Freshwater Biodiversity Water Transfer Project.FISHERIES 21 (9) 8-9

[15] Steel, R.G.D and Torrie, J.H (1980): Principle and Procedure of Statistic McGraw-Hill New York NY, 481pp

[16] Talabi, S.O. (1986). Investment prospects in fish feed Technology Proceedings of the 5th Annual Conference of the Fisheries Society of Nigeria (FISON). Ilorin 22nd -25th Sept. p 200-223.

[17] Vakily, J.M, Froese, R, Palomares, Ma Lourdes D,. and Daniel, P. (1997). European UnionSupports Project to strengthen Fisheries and Biodiversity Management in African,Caribbean and Pacific (ACP) countries. NAGA 20 (1) 4-12

[18] Witte, F.T., Goldschmidt, J.H. Wanink, M.J.P. Van, Oijen, P.C. Goudswaord, E.L.M. Witte-Maas, and N. Bouton (1992). The destruction of an endemic species flock:quantitative data on the decline of the haplochromic species of the Mwanza Gulf ofLake Victoria Environ-Biol-Fishes. In: Melanie L.J. Stiassny (1996). InternationalFreshwater Biodiversity Water Transfer Project. FISHERIES 21 (9) 11. 